\title{
Perceptions of Faculty Developers About the Present and Future of Faculty Development at Historically Black Colleges and Universities
}

\author{
Phyllis Worthy Dawkins \\ Johnson C. Smith University \\ Andrea L. Beach \\ Western Michigan University \\ Stephen L. Rozman \\ Tougaloo College
}

The Historically Black Colleges and Universities Faculty Development Network

The development of faculty at Historically Black Colleges and Universities ( $H B C U s$ ) has been a challenge and commitment since their inception before and after the civil war. Historically, faculty have assumed many roles, but they primarily sought to address the needs of black students. The HBCU Faculty Development Network, founded in 1994, has been instrumental in providing a platform to showcase accomplishments and challenges in education at this unique group of colleges and universities. To address future needs, we surveyed the membership to explore current program goals and influences, practices, and new directions. The results are compared with data for the Professional and Organizational Development Network in Higher Education, with some significant differences discovered. 


\section{Introduction}

Historically Black Colleges and Universities (HBCUs) have a unique history and set of challenges on the American higher education landscape. But, just like other institutions of higher education, they are experiencing internal and external needs and pressure to change. The challenges of creating and promoting change are generally based on the needs of students, faculty, and the institution. Faculty development has increasingly played an important part in change at HBCUs. However, no research has yet focused on the unique development needs of faculty at HBCUs and the ways that faculty development programs can meet those needs. The purpose of this study is to explore the perceptions of faculty developers at HBCUs regarding the issues their faculty and institutions face, and their ability to address the issues they identify. Results of a survey of HBCU faculty developers will be presented and compared to a national survey of faculty developers at a wide range of colleges and universities. We wanted to know what is currently important to them and how the HBCU Faculty Development Network and other agencies such as The Professional and Organizational Development Network in Higher Education (POD) and The Collaboration for the Advancement of College Teaching and Learning can provide the tools for meeting their faculty development challenges. This chapter will begin with a short history of HBCUs and the challenges they have faced and continue to work with today. We will then outline the history of faculty development in HBCUs and the progress made by the HBCU Faculty Development Network. Finally, we will look at the perceptions of faculty developers at HBCUs regarding current and future practices and challenges.

\section{The History and Challenges of HBCUs in Higher Education}

The Higher Education Act of 1965 defines an Historically Black College and University as: "... . any black college or university that was established prior to 1964." The majority of the 105 HBCUs are located in the southeastern states, the District of Columbia, and the Virgin Islands (U.S. Department of Education, 2004b). They consist of 40 public four-year, 11 public two-year, 49 private four-year, and 5 private two-year institutions. Most are more than 100 years old, with Cheyney University of Pennsylvania, founded in 1837, being the oldest of these institutions. Nineteen of the HBCUs are land-grant institutions founded as agricultural, mechanical, and industrial schools as a result of the Morrill Act of 1862 and the second Morrill Act of 1890 (U. S. Department of Education, 2004b). 
Prior to the 1860 s, very few blacks received any form of educational training. By law and according to social customs in the south, it was forbidden to teach blacks to read or write (Browning \& Williams, 1978). Northern missionaries and ex-slaves established schools and colleges for blacks from 1861-1880. A challenge after emancipation was to educate freed slaves and to obtain a squadron of people to educate them. To their rescue came the American Missionary Association, the Freedmen's Bureau, and other ex-slaves. The challenge to black colleges was to take former slaves, or the children of former slaves, educate them for survival, and mold them into people with self-respect and dignity (Thompson, 1978).

The Morrill Act of 1862 allocated funds for the provision of land-grant colleges to foster educational opportunities for all students, especially newly freed blacks. Before the extended Morrill Act of 1890, the primary goal of black colleges was to produce educated leaders for black people (Browning \& Williams, 1978). Black colleges were established to train teachers, preachers, and other key community figures equipped to remedy the despair arising from slavery. But how to educate blacks during this time became a heated debate between Booker T. Washington, a graduate of Hampton Institute, and W.E.B. DuBois, a graduate of Fisk University. Hampton Institute, founded in 1868, led the development of industrial education, followed by Tuskegee Institute. Washington advocated vocational training appropriate for the masses. He believed that since most black people depended upon agriculture for their living, they should be educated in keeping with the requirements of an agriculture society (Washington, 1974). In contrast, DuBois advocated the development of an elite group, "a talented tenth" to teach and lead other blacks. DuBois argued that a liberal arts education provided blacks with the resources for attaining intellectual, social, and political equality (DuBois, 1961).

During the 1890s to the early 1900s, a series of laws were established to limit the education of blacks and to promote industrial training. The extended Morrill Act of 1890 led newly founded land-grant colleges to base their training on the industrial model of education for blacks and whites in southern states. In spite of the debate between DuBois and Washington, early curriculum in black colleges included character building, personal cleanliness, and instruction in both liberal and industrial subjects (Browning \& Williams, 1978). The Plessy v. Ferguson decision of the Supreme Court in 1896 established by law the right to set up separate public institutions for blacks and whites. Black colleges, therefore, were the critical access points to higher education for blacks and crucibles for the development of the black elite and educated working-class alike. 
McKinney (1932) reported that between 1907 and 1932, many black colleges had unparalleled growth. One growth area was graduate school opportunities. As more blacks earned an undergraduate degree, the challenge for many became obtaining a graduate degree. In the early part of the 20th century, graduate training was only available to blacks at a few northern universities or at some privately supported black institutions, such as Fisk University, Howard University, and Atlanta University (Franklin \& Moss, 1994), Eager and ambitious black youths began to prepare themselves for the pursuit of medicine, teaching, engineering, and business. Furthermore, the vocational idea appeared to be dominant in all of these pursuits. However, during that time, black colleges faced challenges in meeting standards of regional and accrediting boards, professionalizing college teaching, updating the liberal arts colleges, raising general intellectual development, and promoting selfreliance and self-education (Florence, 1932). Also, as blacks became more educated and were able to articulate their views on how to educate blacks, they began to publish numerous books and articles in white and black journals (Franklin \& Moss, 1994).

From the 1950 s to the 1970 s, black colleges were impacted by a series of events. The 1954 Supreme Court decision in Brown v. Board of Education declared that racial segregation in public schools deprives black students of equal protection of the law under the 14th Amendment of the Constitution. Title V of the Civil Rights Act of 1964 prohibited institutions that received federal funds from discriminating on the basis of race in hiring, promotion, and admission policies (Browning \& Williams, 1978). This led to social and educational legislation that would change the face of colleges and universities across the country, ensuring black students access to and choices in higher education that had never before been available. It would also change the status and stability of black colleges.

A 2003 report from the U.S. Department of Education included the following statistics about the status of black students in HBCUs:

- Nearly one-quarter of all bachelor's degrees earned by blacks in 1999-2000 were earned at HBCUs.

- Fourteen percent of all blacks enrolled in postsecondary institutions were enrolled in HBCUs in fall 1999.

- Thirteen percent of black, non-Hispanic students were enrolled in HBCUs compared to the total enrollment of all blacks in all colleges and universities in fall 2000. 
Despite recruiting challenges from predominantly white institutions, HBCUs continue today to be critical to the higher education of black students.

\section{The Challenges of Faculty at HBCUs}

The challenges of faculty in HBCUs have evolved over time and have therefore impacted their growth and development. The educational preparation of black teachers after emancipation was a challenge because they first had to be educated before they could be recruited to teach. Many of the teachers were not educated beyond the seventh grade when they began to teach (Litwack, 1998). Litwack also reports that what a teacher could teach was limited by textbooks that were carefully selected by school boards to reflect a white southern point of view.

During emancipation, black teachers played numerous roles apart from instruction. Since they were among the initially educated leaders, they assisted freedmen in contract disputes, engaged in church work, and drafted petitions to the Freedmen's Bureau, state officials, and Congress (Foner, 1989). In 1978 , Thompson reported that some black teachers were expected to provide tutorial counseling sessions and serve as sponsors of student organizations. More importantly, Thompson asserts that black faculty saw their role as preparing disadvantaged black youth for making it in a white-dominated middle-class environment. Today, faculty in black colleges continue to serve in multiple roles that include mentors, advisors, tutors, and administrators.

The quantity and quality of black college faculties have been challenges for a number of years, especially since predominantly white colleges began actively recruiting black faculty in the 1970 s. At one time, black colleges had a faculty that was predominantly black. They were able to recruit and retain outstanding teachers, despite low salaries and poor working conditions (Thompson, 1978). Today, many black teachers have attractive opportunities to join white-college faculties. The number of black teachers at white colleges and universities has steadily increased due to the growing demand for teachers of black studies, the demand for a black presence among teaching personnel at institutions where the number of black students has increased, and affirmative action programs connected to hiring practices (Franklin \& Moss, 1994). However, because of the efforts of many black colleges to also recruit and retain faculty who are black, the U.S. Department of Education (2004a) reports that blacks constitute $60 \%$ of the full-time faculty at HBCUs and whites constitute $27 \%$.

In spite of the opportunity to go to other colleges, many black faculty remain in black colleges because they are dedicated to black youth. The same 
is true for white faculty who are in black colleges. Carrell P. Horton of Fisk University summarized the challenges facing faculty with black students in black colleges as the necessity for student enrollment in remedial courses, dropping of standardized test scores for admission, and perceptions of the student mix, as well as below average faculty salaries and the decline in institutional funds for faculty development (in Drewry \& Doermann, 2001). Ben E. Bailey of Tougaloo College also reported that some students were not prepared for college study (in Drewry \& Doermann, 2001).

\section{:The History of Faculty Development at HBCUs}

Faculty have responded to these challenges in a number of ways. In 1932, Florence described the training of black college teachers by universities as providing in-service training consisting of extension courses, correspondence courses, study clubs, professionalized faculty meetings, syllabus preparation, research and investigation, and leaves of absence.

Horton reported that Fisk University streamlined all curricula, dropped some majors, developed cooperative and dual degree programs, offered limited programs for adult learners, added business and computer science, addressed criteria for and expectations of new hires, and strengthened commitment to faculty development (Drewry \& Doermann, 2001). Tougaloo College instituted a writing across the curriculum program, addressed learning styles, utilized case studies, added community service as a degree requirement, and offered a pre-freshman summer program (Drewry \& Doermann, 2001). Many of these reform efforts were supported through a variety of faculty development programs.

The faculty development movement in private black colleges really did not occur until the 1980s (Drewry \& Doermann, 2001). Many of these programs were funded by Title III, private grants, and foundation grants such as those from the Andrew Mellon Foundation and the Bush-Hewlett Foundation. In 1994, Dean Whitla of Harvard University and Asa Grant Hilliard evaluated the faculty development programs of 23 private colleges for the Bush Foundation and the William and Flora Hewlett Foundation (Bush-Hewlett Grants). They found that the Bush-Hewlett Grants touched the professional lives of many of the faculty in the participating colleges, that project activities helped to improve the quality of teaching, and that virtually all projects concentrated on meeting the needs of students rather than focusing on research or faculty sabbaticals (Drewry \& Doermann, 2001). Selected projects Whitla and Hilliard listed as responding to the needs of the students included computer skills of faculty, writing across the curriculum, faculty travel to conferences on teaching critical 
thinking, general education development, new course development, and learning communities (Drewry \& Doermann, 2001).

\section{The HBCU Faculty Development Network}

The HBCU Faculty Development Network was created in 1994 with a grant from the Bush Foundation to Tougaloo College. The network was founded by Stephen Rozman, a faculty member and the director of the Tougaloo College faculty development grants since 1989, who continues to serve as the network's co-director. The grant coordinating team at Tougaloo worked with Rozman, Bush Foundation officers, and faculty development leaders at various private HBCUs to put an initial conference together. Phyllis Worthy Dawkins, the other co-director from Johnson C. Smith University, Carrell Horton from Fisk University, Barbara Frankle from LeMoyne-Owen College, Argiro Morgan from Xavier University, and Jesse Silverglate from Florida Memorial College became members of the steering committee that founded the network. As the network grew, faculty from public HBCUs were added to the committee, most notably Cecilia Steppe-Jones from North Carolina Central University, J. Jonathan Lewis from Texas Southern University, and M. Shelly Hunter from Norfolk State University.

The Bush Foundation is an important supporter of faculty development efforts at HBCUs that are members of the United Negro College Fund (UNCF), and has also funded The Collaboration for the Advancement of College Teaching and Learning (The Collaboration). The Collaboration has been giving travel grants to faculty from UNCF-affiliated HBCUs to attend their semi-annual faculty development conferences since the 1980s. The experience of attending The Collaboration conferences gave us the idea of creating our own network.

More than 100 people-nearly all serving as presenters-attended the first HBCU Faculty Development Symposium in 1994, which featured presentations in a variety of areas related to faculty development. The response to the initial call for proposals was very positive, and submissions were received by faculty from a wide variety of HBCUs-and a few non-HBCUs. It became clear to all that this effort was filling an important gap by holding a faculty development conference for historically black institutions. In 1994, when there was far less focus on faculty development at minority serving institutions, it was hard to imagine that a startup organization on a shoestring budget could become successfully established. With the success of the initial conference, the steering committee was committed to making the 
symposium an annual event and moving it around to other cities in the Southeast, given the location of most HBCUs.

The mission of the HBCU Faculty Development Network is derived from the rich legacy of HBCUs in providing educational opportunities for underrepresented students. Building on this heritage, the network is committed to promoting effective teaching and student learning through a variety of collaborative activities that focus on faculty enhancement. These collaborative activities are designed to make a connection among teaching, research, and service. The network also facilitates collaboration between faculty and administrators to share individual achievements for collective success in meeting student needs.

The vision of the HBCU Faculty Development Network is to empower faculty to promote effective teaching and learning practices that will enable students to become engaged lifelong learners in an ever-changing society. The network aims to be recognized as the main organization among the 105 HBCUs for advancing the following strands to encourage the delivery of effective teaching and learning: collaborative models, teaching and learning styles/instructional strategies and techniques, curriculum design and revision, diversity and globalization, learning across the curriculum, educational technology, evaluation of assessment and learning, and community service/service learning. The goals of the network are to enhance the teaching and learning process based on the collective experience of HBCUs and to provide leadership and coordination efforts among HBCUs.

The HBCU Faculty Development Symposium has been attracting between 175 and 200 participants every year. Faculty representing the majority of the HBCUs have attended the symposium over the past 11 years, as have some chief academic officers of these institutions. As the network matures, the steering committee wants to understand the unique needs, influences, practices, and challenges of HBCU faculty developers. This understanding can help the network serve the unique needs of HBCUs in the future.

\section{Design, Methods, and Results}

The data reported here is from a survey developed by Mary Deane Sorcinelli of the University of Massachusetts Amherst, and Ann Austin, Pamela Eddy, and Andrea Beach of Michigan State University. During the 2002 POD Conference in Atlanta, Georgia, Sorcinelli and Austin presented the results of the survey- "Understanding Our Present and Future: A Study of POD Professionals." Phyllis Worthy Dawkins, a co-director of the HBCU 
Faculty Development Network, attended their session and met with them to discuss the possibility of administering the survey to our membership. As a result of this and follow-up conversations, all colleagues from the University of Massachusetts Amherst and Michigan State University and members of the HBCU Faculty Development Network agreed to work on the project. Andrea Beach, now of Western Michigan University, took the lead on survey administration and data analysis.

After the Human Welfare Committee at Johnson C. Smith University approved the administration of the survey, it was sent to faculty on the mailing list of the HBCU Faculty Development Network during the spring semester of 2004. Of the 105 surveys sent to faculty representing each institution that was involved in some form of faculty development, 49 responded after a first or second mailing, resulting in a response rate of $47 \%$.

The survey is composed of 18 questions with some sub- or follow-up questions, using Likert-type scales, rankings, and open-ended questions. The data were statistically analyzed using frequencies, means, and analysis of variance. After reporting the results of the demographic data, we will focus on the results of three major questions. The questions address program goals and purposes, current practices, and new directions for faculty development.

\section{Demographics}

In terms of demographics, the titles given by respondents included seniorlevel administrator $(35 \%)$, director or program coordinator $(45 \%)$, and faculty member ( $51 \%)$. Most $(69 \%)$ reported two or more titles, often an administrative title first and faculty or some other role second or third, hence the percentages that add to greater than $100 \%$ (see Table 8.1 ). The mean of their years in faculty development was 7.5 , with a mean of 10 years at their institutions. Forty-six percent of respondents worked in liberal arts colleges, $32 \%$ in comprehensive universities, and the rest in community colleges, research/doctoral institutions, and others. Forty-nine percent of the respondents were from public universities and $51 \%$ were from private institutions, exactly mirroring the number of public and private HBCUs in the country.

The structure of faculty development programs at the institutions included a centralized unit with dedicated staff offering a range of programming and services (31\%); a "clearinghouse" for programs and offerings that are sponsored across the institution, but offering few programs itself (11\%); a committee charged with supporting faculty development (17\%); an individual faculty member or administrator charged with supporting faculty development (31\%); and some other kind of structure (10\%). These structures 
TABLE 8.1

Titles Given by Survey Respondents

\begin{tabular}{lcccc}
\hline & $\begin{array}{c}\text { First } \\
\text { Response }\end{array}$ & $\begin{array}{c}\text { Second } \\
\text { Response }\end{array}$ & $\begin{array}{c}\text { Third } \\
\text { Response }\end{array}$ & $\begin{array}{c}\text { Total and } \\
\% \text { of } \\
\text { respondents } \\
(\mathrm{N}=49)\end{array}$ \\
\hline $\begin{array}{l}\text { Ditle } \\
\text { program coordinator }\end{array}$ & 21 & 0 & 1 & $22-45 \%$ \\
Senior administrator & 14 & 3 & 0 & $17-35 \%$ \\
Faculty member & 8 & 16 & 1 & $25-51 \%$ \\
Midlevel administrator & 3 & 9 & 3 & $15-31 \%$ \\
\hline
\end{tabular}

differed somewhat from the structures found in the national sample of POD respondents, in that there were fewer centralized units (national: 59\%), and more individuals charged with responsibility for faculty development (national: $15 \%$ ). However, they match more closely the national liberal arts college structures (central unit: $24 \%$; individual: $30 \%$ ). Overall, there are a variety of structures for faculty development at HBCUs, and for a movement that started only in the 1980 s, these structures are evidence of the swift growth and development of faculty development on these campuses.

\section{Goals and Purposes}

Developers were asked to respond to 10 statements of goals and purposes that may guide faculty development programs. They rated the degree to which each goal guides their program or unit $(1=$ not at all, $2=$ to a slight degree, $3=$ to a moderate degree, $4=$ to a great degree), and they indicated the three primary purposes that guide their programs. The rankings of primary purposes were converted into percentages of respondents indicating a goal in their "top three" and are reported as such. Developers at HBCUs across all institutional types perceived the top three goals guiding their programs as:

- Creating or sustaining a culture of teaching excellence (mean $=3.4,75 \%$ )

- Responding to and supporting individual faculty members (mean =3.3, $58 \%)$

- Advancing new initiatives in teaching and learning (mean $=3.3,43 \%$ ) 
In a comparable fashion, developers from the national sample of POD members (Austin, Sorcinelli, Eddy, \& Beach, 2003) $(n=499)$ across all institutional types perceived the same top three goals guiding their faculty development programs:

- Creating or sustaining a culture of teaching excellence (mean $=3.7,73 \%$ )

- Responding to and supporting individual faculty members (mean $=3.5$, $56 \%)$

- Advancing new initiatives in teaching and learning (mean $=3.6,49 \%$ )

Austin et al. state that these top goals reflect the longstanding interest of faculty development programs in teaching and learning issues and in strategies to support individual faculty members. In addition, advancing new initiatives in teaching and learning among HBCUs supports their history and mission to advance the education of black students according to the demands of society and the need to be unique in their educational approaches. This statement is further supported by the following secondary goals for HBCUs:

- Acting as a change agent within the institution (mean $=2.9,23 \%$ )

- Supporting departmental goals, planning, and development $($ mean $=2.8,20 \%)$

- Responding to the critical needs of the institution (mean $=3.1,18 \%$ )

These secondary goals support the unique perspective and mission of HBCUs, and it appears that faculty development in HBCUs is more attuned to the need for the institutions to demonstrate their uniqueness. Therefore, faculty developers see responding to the critical needs of the institution as much more within their realm of responsibility. In contrast, the database for POD (Austin et al., 2003) showed the following as secondary goals:

- Acting as a change agent within the institution (mean $=3.2,26 \%$ )

- Fostering collegiality within and among faculty and departments $($ mean $=3.1,26 \%)$

- Providing support for faculty members having difficulty (mean $=2.9$, $17 \%)$

The goals developers at HBCUs consider less influential on their programming consisted of: 
- Providing recognition and reward for excellence in teaching (mean $=2.8$, $18 \%)$

- Fostering collegiality within and among faculty and departments (mean $=2.8,15 \%$ )

- Providing support for faculty members having difficulty with their teaching (mean $=2.9,13 \%)$

- Positioning the institution at the forefront of educational innovation (mean $=2.8,10 \%$ )

In contrast, the POD sample showed the following as the least influential goals:

- Responding to critical needs as defined by the institution (mean $=2.9$, $15 \%)$

- Providing recognition and reward for excellence in teaching (mean $=2.5$, $13 \%)$

- Positioning the institution at the forefront of educational innovation $($ mean $=2.6,7 \%)$

- Supporting departmental goals and development (mean $=2.5,7 \%$ )

Clearly, although the HBCUs share primary faculty development goals with the larger national field, their secondary driving purposes are somewhat more institutionally oriented.

\section{Current Practices}

The survey also sought to determine the extent to which faculty development programs are currently offering services pertaining to 21 different issues that potentially affect faculty. Respondents were asked to indicate the extent to which they believe it is important for their programs to offer services pertaining to those issues ( $1=$ not at all, $2=$ to a slight extent, $3=$ to a moderate extent, $4=$ to a great extent). They also reported on the same scale the extent to which their faculty development programs offer services to address those issues. Table 8.2 compares the ratings of $\mathrm{HBCU}$ faculty developers with the responses of the national group. ANOVAs were run comparing the HBCU responses to the responses from the national sample as well as from different types of institutions. Significant differences are reported for the comparisons. 
TABLE 8.2

Current Issues for Faculty Development

\begin{tabular}{|c|c|c|c|c|}
\hline \multirow[b]{2}{*}{ Current Issues } & \multicolumn{2}{|c|}{ HBCUs } & \multicolumn{2}{|l|}{ POD } \\
\hline & Important & Offer & Important & Offer \\
\hline Assessment of student learning outcomes & 3.66 & $3.00^{*}$ & 3.43 & 2.57 \\
\hline Teaching underprepared students & $3.32^{* *}$ & $2.63^{* *}$ & 2.75 & 1.98 \\
\hline $\begin{array}{l}\text { The shifting characteristics/demographics } \\
\text { of students }\end{array}$ & $3.21^{*}$ & 2.32 & 2.85 & 2.24 \\
\hline $\begin{array}{l}\text { Integrating technology into traditional } \\
\text { teaching and learning settings }\end{array}$ & 3.61 & 3.55 & 3.51 & 3.28 \\
\hline Teaching in online and distance environments & 3.05 & 2.53 & 2.96 & 2.63 \\
\hline Multiculturalism and diversity related to teaching & 3.43 & 2.74 & 3.36 & 2.75 \\
\hline Teaching for student-centered learning & 3.58 & 2.89 & 3.69 & $3.25^{*}$ \\
\hline Teaching adult learners & $3.05^{*}$ & 2.39 & 2.63 & 2.08 \\
\hline Active, inquiry-based, or problem-based learning & 3.37 & 2.84 & 3.51 & 3.00 \\
\hline Writing across the curriculum/writing to learn & $3.53^{* *}$ & $2.89^{*}$ & 3.06 & 2.46 \\
\hline Team teaching & $3.00^{* *}$ & 2.13 & 2.49 & 1.91 \\
\hline Scholarship of teaching & 3.26 & 2.58 & 3.28 & 2.57 \\
\hline New faculty development (e.g., mentoring) & 3.45 & 2.82 & 3.60 & 3.03 \\
\hline $\begin{array}{l}\text { Mentoring faculty from underrepresented } \\
\text { populations }\end{array}$ & 3.00 & 1.92 & 2.86 & 1.90 \\
\hline Course/teaching portfolios & 3.16 & 2.37 & 2.97 & 2.46 \\
\hline Peer review & 2.95 & 2.13 & 2.93 & 2.26 \\
\hline Post-tenure review & $2.89^{* *}$ & 1.92 & 2.33 & 1.62 \\
\hline Graduate student teaching development & 2.11 & 1.47 & 2.46 & $2.07^{\star *}$ \\
\hline Course and curriculum reform & $3.37^{*}$ & 2.45 & 2.98 & 2.40 \\
\hline General education reform & $3.16^{* *}$ & $2.51^{* *}$ & 2.60 & 1.98 \\
\hline Community service learning & $3.26^{* *}$ & $2.47^{*}$ & 2.67 & 2.08 \\
\hline
\end{tabular}

As shown in Table 8.2, the three most important issues to HBCU faculty developers-assessment of student learning outcomes, integrating technology into traditional teaching and learning settings, and teaching for studentcentered learning - are the same as those for the POD faculty developers. 
HBCU faculty developers reported offering services to address assessment more than the POD group, and the POD group reported addressing teaching for student-centered learning to a greater extent. New faculty development, active or inquiry-based teaching and learning, and the scholarship of teaching were also equally important to the two groups. Interestingly, both judged addressing multiculturalism and diversity as important to offer, but were equal in their assessment that services to address the issue were far below the perceived need for them.

The next most important issues for HBCUs diverge strongly from the POD respondents' priorities and are also addressed by HBCU faculty development programming to a greater extent. These include writing across the curriculum, teaching underprepared students, addressing the changing characteristics and demographics of students, community service learning, course and curriculum reform, general education reform, and teaching adult learners. These issues closely match the strands developed by the network to improve teaching and learning at $\mathrm{HBCUs}$.

\section{¿Perceptions of Important Future Directions}

HBCU Network developers were asked to respond to a number of new challenges and pressures on institutions which affect faculty work, both in terms of how important they think it is to address those issues through faculty development and the extent to which their institutions are already responding ( $1=$ not at all, $2=$ to a slight extent, $3=$ to a moderate extent, $4=$ to a great extent). Table 8.3 contains a comparison of $H B C U$ developer responses with those of the POD respondents. Again, ANOVAs were run to assess the difference between $\mathrm{HBCU}$ and POD responses.

For both groups, the training and support of adjunct and part-time faculty, the changing roles and rewards for faculty, and balancing multiple faculty roles were important. For HBCUs, however, other issues were of equal or greater importance. Unit and program evaluation and assessment, departmental leadership and management, the ethical conduct of faculty work, and supporting institutional change priorities were all rated significantly higher by HBCU respondents than by POD respondents. Further, HBCUs appear to be addressing those pressing new challenges to a much greater degree than their national counterparts. $\mathrm{HBCU}$ respondents rated preparing the future professoriate as a greater concern than did POD respondents, but the national sample indicated that their campuses are addressing this issue to a greater extent than the HBCU developers. 
TABLE 8.3

New Challenges and Pressures for Faculty Development

\begin{tabular}{|c|c|c|c|c|}
\hline \multirow[b]{2}{*}{ New Challenges and Pressures } & \multicolumn{2}{|c|}{ HBCUs } & \multicolumn{2}{|c|}{ POD } \\
\hline & Important & Offer & Important & Offer \\
\hline Departmental leadership and management & $3.47^{*}$ & 2.17 & 3.10 & 1.94 \\
\hline Changing faculty roles and rewards & 3.30 & 2.17 & 3.18 & 2.12 \\
\hline Training and support for part-time/adjunct faculty & 3.38 & 1.88 & 3.26 & 2.11 \\
\hline Ethical conduct of faculty work & $3.38^{* *}$ & $2.17^{*}$ & 2.81 & 1.84 \\
\hline Preparing the future professoriate & $3.26^{*}$ & 2.11 & 2.87 & 2.20 \\
\hline Support of institutional change priorities & $3.26^{*}$ & 2.46 & 2.89 & 2.34 \\
\hline Balancing multiple faculty roles & 3.33 & 2.28 & 3.08 & 2.12 \\
\hline Community-based research & $2.89^{* *}$ & 1.91 & 2.18 & 1.64 \\
\hline Outreach/service activities & $3.22^{* *}$ & $2.45^{* *}$ & 2.37 & 1.99 \\
\hline $\begin{array}{l}\text { Faculty and departmental entrepreneurship } \\
\text { (e.g., consulting on behalf of the institution) }\end{array}$ & $2.59^{* *}$ & 1.64 & 1.75 & 1.44 \\
\hline Unit/program evaluation & $3.54^{* *}$ & $2.58^{*}$ & 2.70 & 2.20 \\
\hline Program assessment (e.g., accreditation) & $3.50^{* *}$ & $3.09^{* *}$ & 2.76 & 2.47 \\
\hline Collaborative departmental work teams & $3.11^{* *}$ & $2.30^{* *}$ & 2.60 & 1.76 \\
\hline Interdisciplinary collaborations & 3.20 & 2.37 & 3.05 & 2.24 \\
\hline Commitment to civic life/the public good & $3.06^{*}$ & $2.42^{\star *}$ & 2.60 & 1.97 \\
\hline Post-tenure review & $3.02^{*}$ & 1.98 & 2.37 & 1.69 \\
\hline Faculty roles in learning communities & 3.15 & 2.21 & 2.83 & 1.95 \\
\hline
\end{tabular}

${ }^{*} \mathrm{p}=.05$

${ }^{* *} \mathrm{p}=.01$

\section{Discussion and Conclusion}

HBCUs have had unique cultures, missions, and challenges throughout their more than 100 years of existence. In recent decades HBCUs have had to become very creative in supporting themselves and their missions as changes in society have threatened their survival. Faculty development has become a key ingredient in the ability of HBCUs to survive and thrive serving a student population that is disproportionately disadvantaged and underprepared. The HBCU Faculty Development Network serves as a consortium within which HBCU faculty developers can support each other, share ideas, and plan for change. 
The program structures reported by HBCUs depict movement toward institutionalization of faculty development. More than two-thirds of respondents are part of a centralized unit with dedicated staff who are responsible for faculty development programming, and the involvement of senior-level administrators and directors indicates the centrality of faculty development on these campuses.

The program influences, current issues, and new challenges reported here highlight the unique missions and strengths of HBCUs and reinforce the idea that different types of institutions have different needs in terms of faculty development (Austin, Sorcinelli, Eddy, \& Beach, 2003). HBCU faculty developers indicated a number of areas of concern and services that were not high priorities for the national sample, in particular, issues of program and institutional assessment and support, community service learning, outreach, commitment to civic life, and writing across the curriculum.

The HBCU Faculty Development Network has always been responsive to the needs of faculty in our institutions. The results of the survey can be used to share with the membership in planning future activities, including the annual symposium and the summer institute, and with administrators and faculty to assist them with their own institutional planning.

\section{References}

Austin, A. E., Sorcinelli, M. D., Eddy, P. L., \& Beach, A. L. (2003). Envisioning responsive faculty development: Perceptions of faculty developers about the present and future of faculty development. Paper presented at the 83rd annual meeting of the American Educational Research Association, Chicago, IL.

Browning, J. E. S., \& Williams, J. B. (1978). History and goals of black institutions of higher learning. In C. V. Willie \& R. R. Edmonds (Eds.), Black colleges in America (pp. 68-93). New York, NY: Teachers College Press.

Drewry, H. N., \& Doermann, H. (2001). Stand and prosper: Private black colleges and their students. Princeton, NJ: Princeton University Press.

DuBois, W. E . B. (1961). The souls of black folks. Greenwich, CT: Fawcett.

Florence, C. W. (1932). Critical evaluation of present policies and practices of Negro institutions of higher education. In T. E. McKinney, Higher education among Negroes (pp. 39-58). Charlotte, NC: Johnson C. Smith University.

Foner, E. (1989). Reconstruction: America's unfinished revolution, 1863-1877. New York, NY: Perennial. 
Franklin, J. H., \& Moss, A. A., Jr. (1994). From slavery to freedom: A history of African Americans (7th ed.). New York, NY: Alfred A. Knopf.

Litwack, L. F. (1998). Trouble in mind: Black southerners in the age of Jim Crow. New York, NY: Alfred A. Knopf.

McKinney, T. E. (1932). Higher education among Negroes. Charlotte, NC: Johnson C. Smith University.

Thompson, D. C. (1978). Black college faculty and students: The nature of their interaction. In C. V. Willie \& R. R. Edmonds (Eds.), Black colleges in America (pp. 180-194). New York, NY: Teachers College Press.

U.S. Department of Education. (2003). Status and trends in the education of blacks (NCES 2003-034). Retrieved May 15, 2005, from http://nces.ed.gov /pubs2003/2003034.pdf

U.S. Department of Education. (2004a). Historically Black Colleges and Universities, 1976 to 2001 (NCES 2004-062). Washington, DC: Government Printing Office.

U. S. Department of Education. (2004b). White house initiative on Historically Black Colleges and Universities. Retrieved May 15, 2005, from http://www.ed.gov/ about/inits/list/whhbcu/edlite-index.html

Washington, B. T. (1974). Up from slavery. New York, NY: Dell. 